\title{
Rancang Bangun Hanyu Shuiping Kaoshi (HSK) Mobile Learning Berbasis Android
}

\author{
Winnie Alison \\ Program Studi Teknik Informatika \\ Politeknik Caltex Riau \\ winnie15ti@mahasiswa.pcr.ac.id
}

\author{
Indah Lestari \\ Program Studi Sistem Informasi \\ Politeknik Caltex Riau \\ indah@pcr.ac.id
}

\author{
Dadang Syarif Sihabudin Sahid \\ Program Studi Sistem Informasi \\ Politeknik Caltex Riau \\ dadang@pcr.ac.id
}

\begin{abstract}
Abstrak - Hanyu Shuping Kaoshi (HSK) merupakan sebuah tes kemampuan berbahasa Mandarin berstandar internasional dimana untuk mempelajari HSK dibutuhkan biaya yang tidak sedikit per pertemuannya. Pada aplikasi yang telah ada, untuk mempelajari HSK dari level 1 hingga 6, pengguna harus meng-install aplikasi secara terpisah sehingga penggunaan memori tidak efisien. Dari permasalahan tersebut maka dibangunlah Hanyu Shuiping Kaoshi (HSK) mobile learning ini. Sistem ini berisi HSK level 1 hingga 6 dan menggunakan voice recognition untuk mengetahui pelafalan setiap kosakata. Penyimpanan data pada aplikasi ini menggunakan database MySQL untuk menampung materi dan kosakata, serta database Firebase untuk menampung forum dan personal chat. Sistem ini terbagi atas 3 platform yaitu 1 aplikasi Android member, 1 aplikasi Android admin, dan 1 web admin menggunakan PHP. Berdasarkan pengujian fungsionalitas yang dilakukan, sistem yang dibangun telah berjalan sesuai dengan fungsinya. Pada pengujian usabilitas yang dilakukan oleh 55 orang terhadap aplikasi member diperoleh nilai sebesar 81,2 dan 81 untuk aplikasi admin yang menunjukkan bahwa kedua aplikasi yang dibangun dinilai acceptable. Pada pengujian expert review diperoleh bahwa aplikasi ini telah sesuai dengan standar HSK sehingga sesuai untuk pengguna yang ingin mempelajari HSK. Pada pengujian berpasangan (paired sample), didapatkan rata-rata nilai pengguna sesudah menggunakan aplikasi $(160,27)>$ ratarata nilai pengguna sebelum menggunakan aplikasi $(200,31)$, sehingga aplikasi ini berhasil secara signifikan. Dengan ini maka dapat disimpulkan bahwa aplikasi yang dibangun ini dapat menjadi solusi untuk memudahkan penguna mempelajari HSK.
\end{abstract}

Kata Kunci: Android, Firebase, HSK, mobile learning, MySQL, PHP, voice recognition.

\section{PENDAHULUAN}

Hanyu Shuiping Kaoshi (漢語水平考試, 汉语水平考试, atau pinyin: Hànyǔ Shuíping Kăoshi), disingkat HSK, adalah sebuah tes kemampuan berbahasa Mandarin/China yang berstandar internasional, dimana tes ini berfokus kepada kemampuan orang yang bukan berdomisili di Tiongkok untuk menggunakan bahasa Mandarin sebagai bahasa untuk berkomunikasi dalam sehari-hari, belajar, maupun bekerja [1].

HSK memiliki 6 level kesulitan dari pemula hingga tingkat lanjut berdasarkan kosa kata yang dimiliki oleh masing-masing individu. Dimana pada level 1 orang dapat memahami dan mengunakan kata dan kalimat sederhana untuk berkomunikasi, hingga level 6 yang memungkinkan orang dapat dengan mudah memahami setiap informasi yang dikomunikasikan dalam Bahasa Mandarin dan mampu dengan lancar mengekspresikan diri dalam bentuk tertulis ataupun lisan.

Seiring dengan perkembangan teknologi, banyak tercipta inovasi berupa pembelajaran melalui media elektronik menggunakan android yang lebih dikenal sebagai m-learning atau mobile learning. Menurut Quinn (2010) mengatakan bahwa Mobile Learning adalah bagian dari sebuah komputasi selular dimana penerapannya pada perangkat/alat komunikasi nirkabel yang kecil dan bisa dibawa kemana saja dan $e$ learning (sebuah pembelajaran yang menggunakan teknologi dalam): bisa diakses dimana saja, terdapat sebuah fitur pencarian, terjadi banyak interaksi didalamnya, adanya pembelajaran yang efektif dan sistem penilaian berdasarkan tugas, melakukan pengujian dengan simulasi ujian, e-learning yang bersifat mandiri dari sisi lokasi dalam ruang atau waktu [2].

Pada era sekarang, banyak sekali anak-anak hingga orang dewasa yang ingin mempelajari bahasa Mandarin khusus HSK dimana apabila ingin menetap di luar negeri seperti China atau Beijing ataupun ingin melamar pada sebuah perusahaan yang memerlukan tingkat profisiensi Mandarin sesuai tuntutan pekerjaan, mereka harus lolos HSK pada level tertentu. Namun untuk mempelajari HSK itu sendiri, dibutuhkan biaya yang tidak sedikit di tempat kursus Bahasa Mandarin. Tempat kursus tersebut menyediakan beberapa pilihan untuk belajar dari dasar hingga pembelajaran khusus untuk persiapan HSK yang berkisar antara 100-500 ribu Rupiah per pertemuan.

Berdasarkan uraian diatas, dibangunlah sebuah sistem dengan judul "Rancang Bangun HSK Mobile Learning berbasis Android". Dengan sistem ini pengguna dapat mempelajari dan menambah kosa kata mandarin, mempelajari materi, mengerjakan contoh soal dari HSK, melakukan pengumpulan tugas, forum diskusi dengan yang lainnya, melakukan chat dengan admin mengenai materi yang kurang dimengerti, penggunaan voice recognition dimana pengguna 
dapat mendengarkan pelafalan kosa kata menggunakan audio atau suara. Aplikasi ini mencakup HSK level 1-6 dimana pada penelitian sebelumnya belum ada yang membuatnya dan pada aplikasi yang terdapat di Playstore yang hanya membuatnya secara parsial/hanya 1 level saja sehingga pengguna harus menginstall aplikasi yang banyak untuk mempelajari level 16. Aplikasi ini terintegrasi dengan MySQL sehingga admin dapat memasukkan materi, melakukan chatting dan berdiskusi di forum melalui Firebase.

\section{METODOLOGI PENELITIAN}

Metodologi yang digunakan dalam membangun sistem ini adalah:

A. Studi Literatur

Mencari referensi teori yang saling berkaitan dengan masalah yang ditemukan. Pengumpulan materi dilakukan seperti buku-buku dan jurnal mengenai HSK, mobile learning, Android, dan database yang digunakan.

B. Observasi

Melakukan pengamatan terhadap aplikasi sejenis yang sudah pernah ada di dunia dan membandingkannya dengan aplikasi yang dibuat.

C. Perancangan Sistem

Setelah melakukan studi literatur dan observasi, maka dilakukan perancangan-perancangan secara rinci mengenai bagaimana sistem atau aplikasi berjalan.

D. Implementasi Sistem

Melakukan pembuatan sistem dengan menerapkan perancangan yang telah dibuat.

E. Pengujian

Setelah merancang bangun HSK mobile learning berbasis Android ini, maka dilakukanlah tahapan pengujian dimana dilakukan kuisioner pra penelitian untuk mengetahui hasil pembelajaran dari aplikasi.

F. Analisis dan Evaluasi

Setelah melakukan implementasi dan pengujian, dilakukan beberapa analisis dan evaluasi dari hasil yang telah didapat dan dilakukan pembuatan laporannya.

\section{HASIL DAN PEMBAHASAN}

Sebelum melakukan implementasi sistem, perlu dilakukan analisa dan perancangan untuk mempermudah implementasi sistem.

\section{A. Arsitektur Sistem}

Arsitektur sistem digunakan untuk mengetahui arsitektur dari sistem yang akan dibuat.

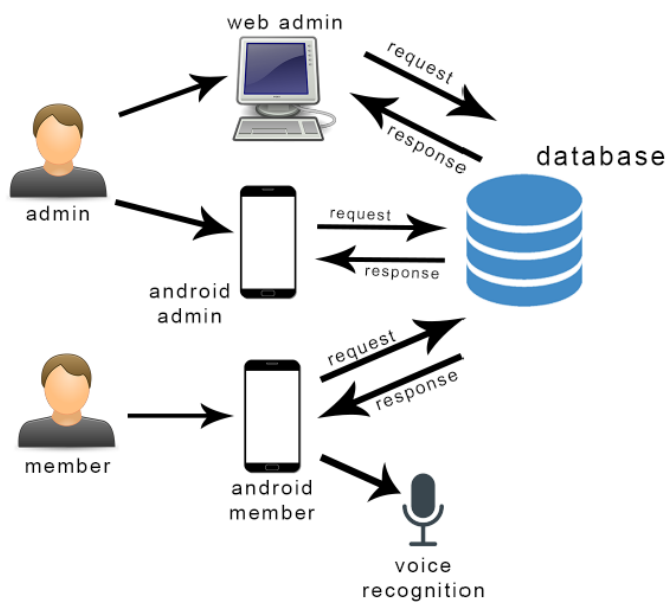

Gambar 1. Arsitektur Sistem.

Pada Gambar 1 terdapat dua pengguna (admin dan member) yang menggunakan sebuah sistem atau aplikasi Android untuk pembelajaran. Namun pada admin, terdapat sebuah aplikasi berbasis web untuk penginputan data. Ketiga sistem tersebut telah terintegrasi dengan database dan pada sistem android untuk member terdapat voice recognition untuk pelafalan kosakata yang ada.

\section{B. Use Case Diagram}

Use Case Diagram menjelaskan urutan kegiatan yang dilakukan oleh aktor dan sistem untuk mencapai sebuah tujuan tertentu.

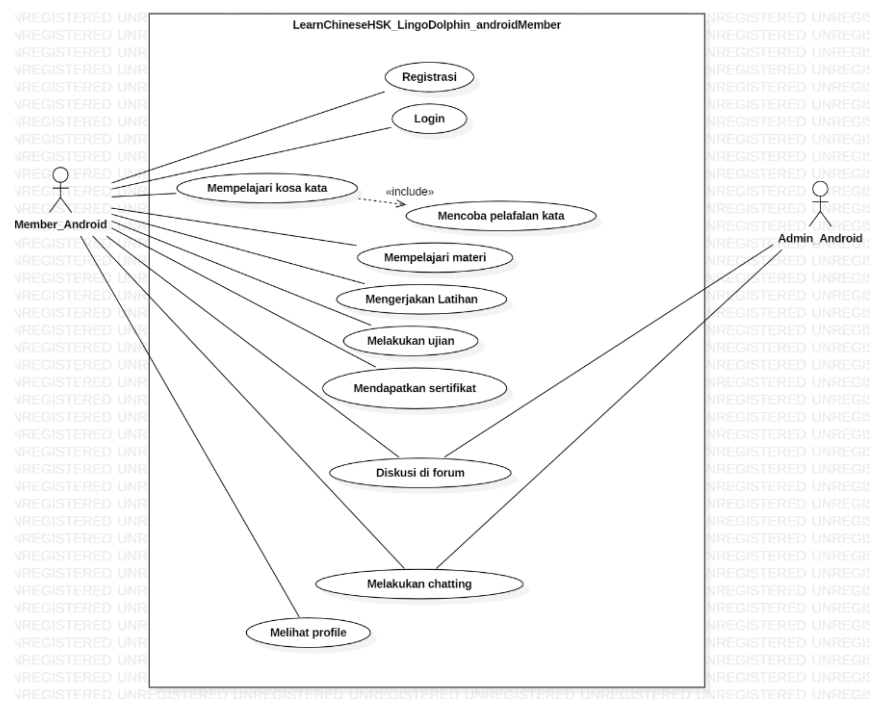

Gambar 2. Use Case Diagram Android Member. 


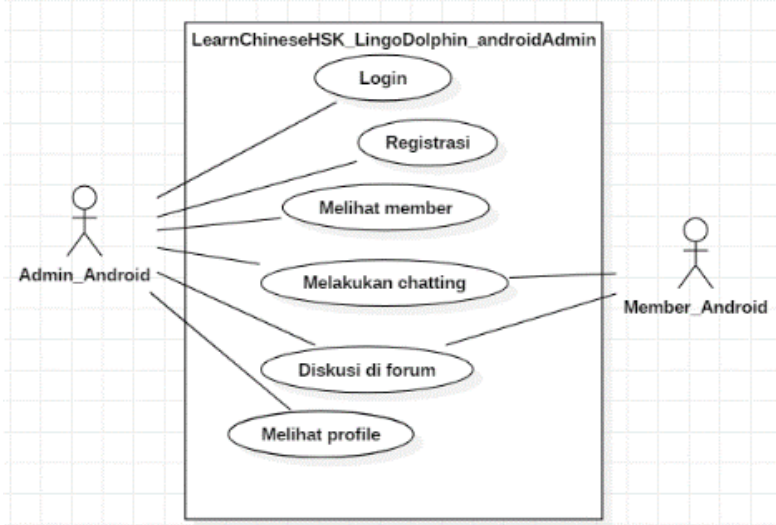

Gambar 3. Use Case Diagram Android Admin.

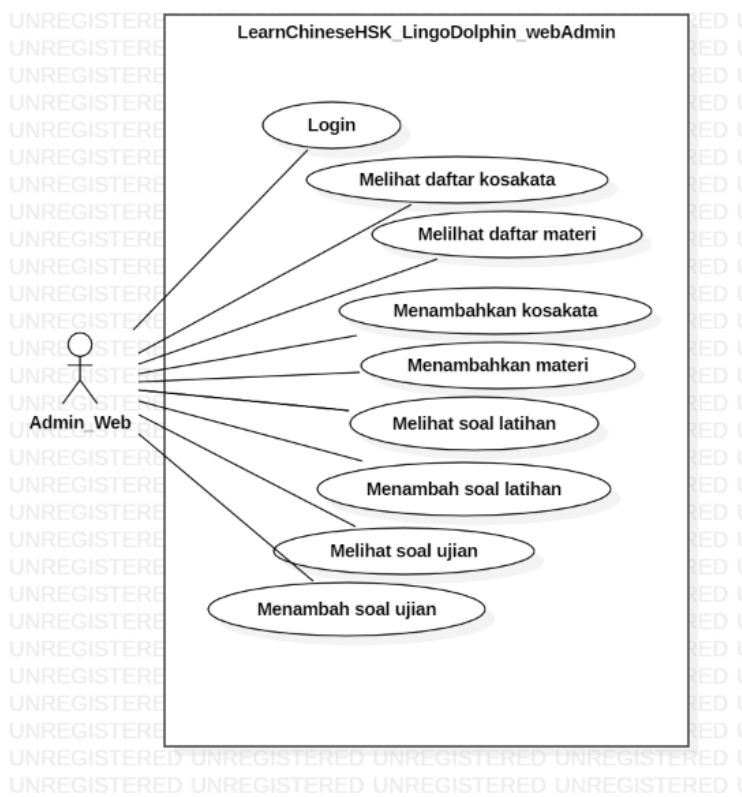

Gambar 4. Use Case Diagram Web Admin.

Pada Gambar 2 berisi interaksi antara member dan admin dimana member dapat melakukan registrasi, login, mempelajari kosakata, mempelajari materi, mengerjakan latihan, melakukan ujian, mendapatkan sertifikat, diskusi di forum, melakukan chatting, dan melihat profile. Sedangkan admin dapat melakukan diskusi di forum dan melakukan chatting dengan member. Pada Gambar 3, dapat dilihat interaksi antara admin dan member dimana admin dapat melakukan registrasi, login, melakukan diskusi di forum, melakukan chatting, melihat daftar member, dan melihat profile. Pada gambar 4, dapat dilihat interaksi admin dimana admin dapat melakukan login dan melakukan penambahan ataupun melihat data yang telah dimasukkan.

\section{User Interface}

Pada user interface ini berisi tampilan antar muka dari sistem yang telah dibuat.

- Tampilan Login dan Registrasi

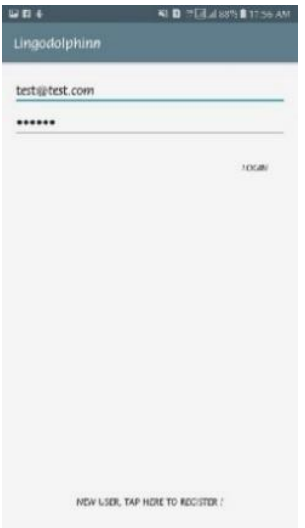

Gambar 5.

Tampilan Login.

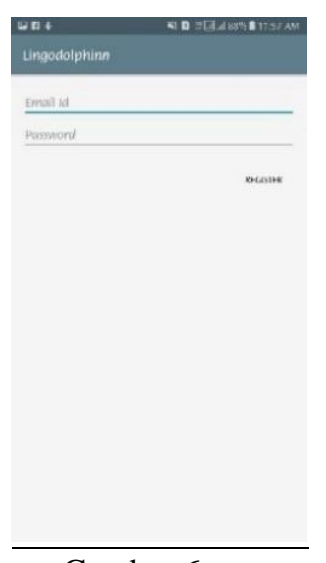

Gambar 6.

Tampilan Registrasi.

Pada Gambar 5, pengguna harus mengisi username dan password apabila telah terdaftar. Pada Gambar 6, apabila pengguna belum terdaftar, pengguna harus menekan New User, Tap Here to Register! untuk mendaftarkan diri.

- Tampilan Beranda

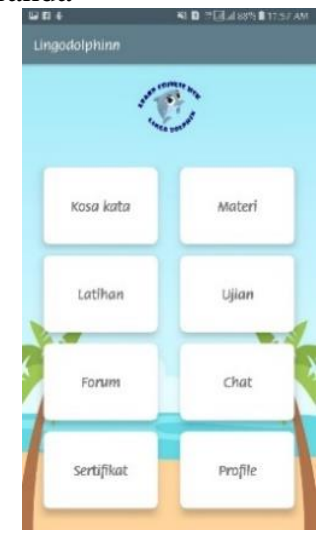

Gambar 7. Tampilan Beranda.

Tampilan setelah melakukan login ataupun registrasi.

- Tampilan kosakata dan materi

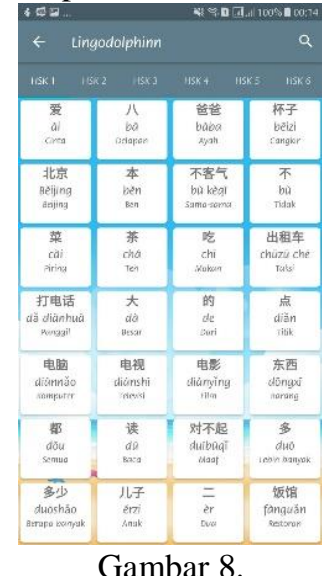

Gambar 8.

Tampilan Kosakata.

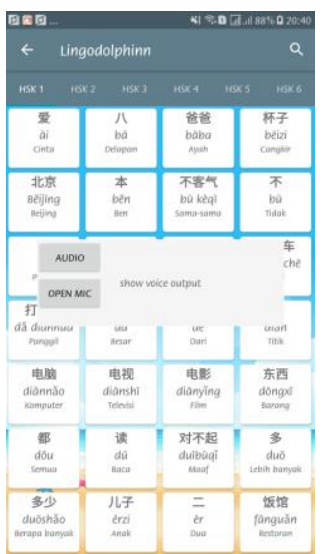

Gambar 9.

Tampilan Setelah Menekan Kosakata. 


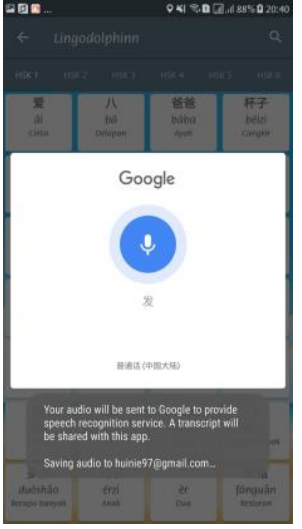

Gambar 10.

Mencoba Pelafalan.

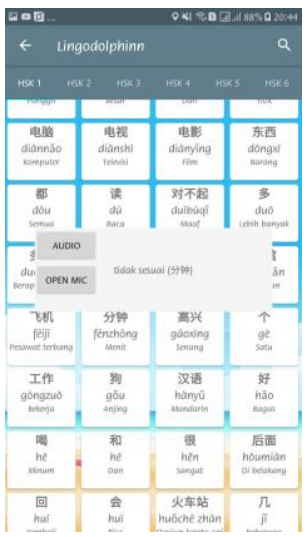

Gambar 12.

Apabila Pelafalan Salah.

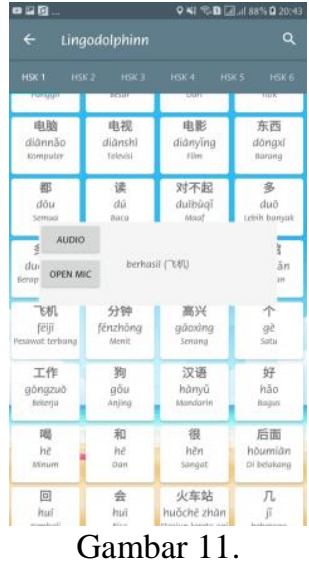

Apabila Pelafalan Benar.

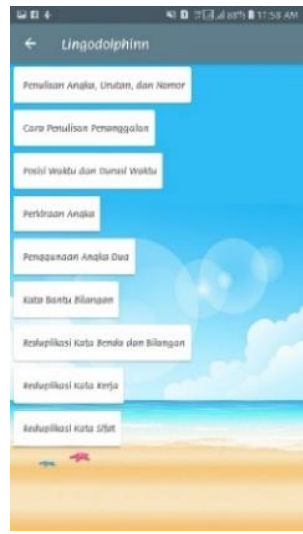

Gambar 13

Tampilan Materi.

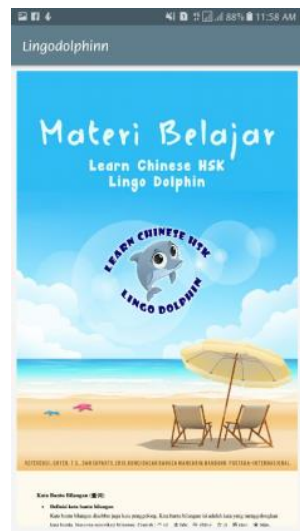

Gambar 14. Materi yang Telah Dipilih

Pada Gambar 8, berisi daftar kosakata untuk setiap level HSK. Apabila pengguna ingin mendengar pelafalan atau pengucapan dari sebuah kata, pengguna dapat menekan kosakata tersebut dan pelafalan dari kata tersebut akan keluar (Gambar 9). Jika pengguna ingin mendengarkan audio secara berulang kali dapat menekan tombol "audio" dan untuk mencoba pelafalan yang telah didengar, pengguna dapat menekan tombol "open mic" dan mengucapkan pelafalannya. Apabila pengguna dapat mengucapkan pelafalan kata tersebut dengan baik maka akan muncul tulisan "berhasil (tulisan Mandarin)" seperti yang ditunjukkan pada Gambar 11 dan apabila pelafalan tidak sesuai dengan tulisannya maka akan muncul tulisan "tidak sesuai (tulisan Mandarin)" seperti yang ditunjukkan pada gambar 12. Pada gambar 13, berisi list materi dari pembelajaran HSK. Apabila materi ini ditekan, maka akan keluar materinya dan pengguna bisa membaca materi tersebut (gambar 14).

- Tampilan latihan dan ujian

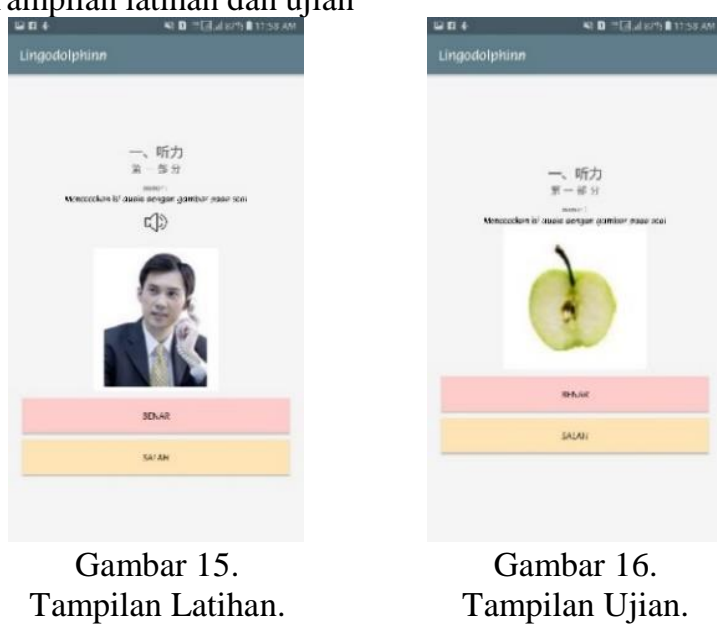

Pada gambar 15, berisi soal latihan sesuai status level HSK sekarang. Apabila pengguna mengerjakan latihan ini, maka pengguna akan mendapatkan nilai. Pada gambar 16, berisi soal ujian sesuai status level HSK sekarang. Apabila pengguna mengerjakan ujian ini, maka pengguna akan mendapatkan nilainya dan akan langsung ter-update di database.

- Tampilan diskusi dan chatting

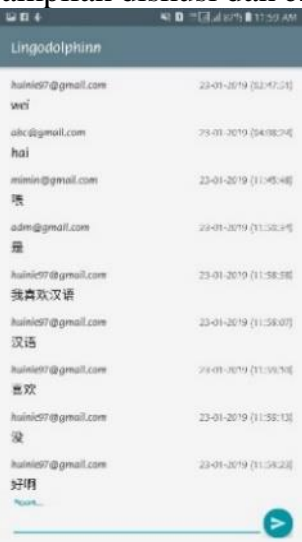

Gambar 17

Tampilan forum
Gambar 18

Tampilan chatting

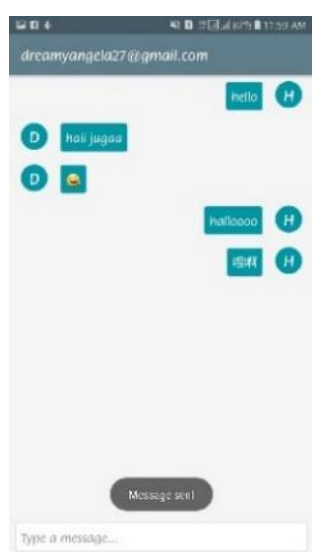

Pada Gambar 17, berisi forum untuk membahas atau bertanya HSK yang berisi banyak orang (lebih dari 2 orang). Pada Gambar 18, berisi percakapan antar dua orang pengguna dan pengguna bisa memilih ingin melakukan chat dengan orang-orang yang ada di dalam list. 
- Tampilan sertifikat dan profile

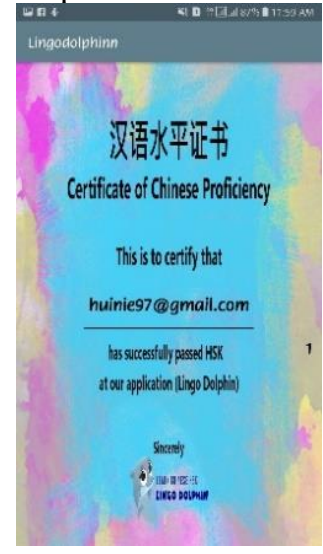

Gambar 19.

Tampilan Sertifikat.

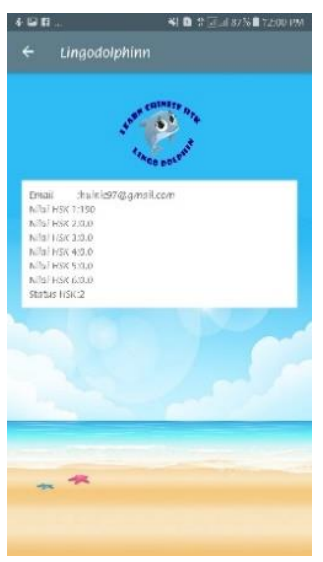

Gambar 20.

Tampilan Profile.
Pada Gambar 19, berisi sertifikat kelulusan hsk yang telah dilewati. Pada Gambar 20, berisi profile dari pengguna.

\section{Pengujian}

\section{Pengujian Fungsionalitas}

Pengujian fungsionalitas berfungsi untuk melihat apakah semua proses pada fitur aplikasi yang ada telah berjalan sesuai dengan hasil yang diharapkan atau tidak. Pengujian ini dilakukan dengan membuat tabel berisi alur dan fitur yang digunakan didalam system beserta hasil yang diinginkan. Kemudian responden akan mencoba menggunakan aplikasi dan melakukan pengujian apakah hasil sebenarnya (yang terjadi ketika pengujian) sesuai dengan hasil yang diinginkan. Berdasarkan hasil analisis pengujian fungsionalitas dari aplikasi yang telah dibangun dan diujikan kepada 55 orang secara acak bahwa seluruh fungsi dari rancang bangun Hanyu Shuiping Kaoshi (HSK) mobile learning berbasis Android telah berjalan dengan baik dan sesuai dengan output yang diharapkan. Aplikasi telah memberikan output yang sesuai dengan inputan yang diberikan oleh pengguna.

\section{Pengujian Usabilitas}

Pengujian usabilitas dilakukan dengan metode SUS (System Usability Scale). Metode ini digunakan untuk mengetahui reaksi dari pengguna dan mendapatkan informasi mengenai kualitas dari aplikasi yang dibangun. Untuk mendapatkan hal tersebut, pengguna perlu menggunakan aplikasi terlebih dahulu. Kemudian pengguna diminta untuk mengisi kuisioner yang dapat dilihat pada Tabel 1 .

Responden dari pengujian ini berasal dari masyarakat umum dengan rentang usia 15-41 tahun yang dilakukan secara acak terhadap 50 orang yang menguji aplikasi Android member dan 5 orang yang menguji aplikasi Android admin.

Rekapitulasi dari responden ini diolah menggunakan metode SUS dengan rumus yang telah ditentukan. Berdasarkan hasil pengujian usabilitas yang telah dilakukan terhadap kedua aplikasi (member dan admin), maka didapatkan hasil rata-rata skor usabilitas untuk aplikasi Android member sebesar 70,67 dan hasil rata-rata skor usabilitas untuk aplikasi Android admin sebesar 81. Berdasarkan perhitungan metode SUS, rentang skor SUS yang nilainya lebih besar dari 70 termasuk ke dalam kategori acceptable. Hasil skor SUS yang telah didapatkan yakni 70,67 untuk member dan 81 untuk admin menunjukkan bahwa aplikasi yang dibangun bersifat acceptable.

Tabel 1. Kuisioner SUS.

\begin{tabular}{|c|c|c|c|c|c|c|}
\hline No & Pernyataan & $\begin{array}{l}\mathbf{S} \\
\mathbf{T} \\
\mathbf{S}\end{array}$ & $\begin{array}{l}\mathbf{T} \\
\mathbf{S}\end{array}$ & $\mathbf{N}$ & $\mathbf{S}$ & $\begin{array}{l}\mathbf{S} \\
\mathbf{S}\end{array}$ \\
\hline 1. & $\begin{array}{l}\text { Saya rasa saya akan secara rutin menggunakan } \\
\text { aplikasi ini. }\end{array}$ & & & & & \\
\hline 2. & $\begin{array}{l}\text { Saya rasa aplikasi ini terlalu kompleks dan } \\
\text { tidak dibutuhkan. }\end{array}$ & & & & & \\
\hline 3. & $\begin{array}{l}\text { Saya merasa bahwa aplikasi yang dibangun } \\
\text { mudah untuk digunakan. }\end{array}$ & & & & & \\
\hline 4. & $\begin{array}{l}\text { Saya memerlukan bantuan dari teknisi } \\
\text { (pembangun aplikasi) untuk menggunakan } \\
\text { aplikasi ini. }\end{array}$ & & & & & \\
\hline 5. & $\begin{array}{l}\text { Saya merasakan fitur-fitur yang terdapat pada } \\
\text { aplikasi ini sudah berjalan dengan baik antara } \\
\text { satu dengan lain. }\end{array}$ & & & & & \\
\hline 6. & 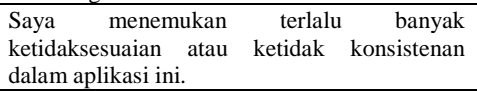 & & & & & \\
\hline 7. & $\begin{array}{l}\text { Saya rasa orang-orang akan dapat dengan } \\
\text { mudah dan cepat dalam menggunakan aplikasi } \\
\text { ini. }\end{array}$ & & & & & \\
\hline 8. & $\begin{array}{l}\text { Saya merasa aplikasi ini sangat sulit untuk } \\
\text { digunakan. }\end{array}$ & & & & & \\
\hline 9. & $\begin{array}{l}\text { Saya merasa sangat percaya diri dalam } \\
\text { menggunakan aplikasi ini. }\end{array}$ & & & & & \\
\hline 10. & $\begin{array}{l}\text { Saya perlu belajar terlebih dahulu untuk } \\
\text { memulai menggunakan aplikasi ini. (melihat } \\
\text { buku panduan). }\end{array}$ & & & & & \\
\hline
\end{tabular}

\section{Pengujian Expert Review}

Expert Review yang dilakukan pada penelitian ini digunakan untuk mendapatkan informasi mengenai kesesuaian kosakata, materi, dan juga soal-soal yang digunakan untuk latihan maupun simulasi ujian. Pengujian expert review ini dilakukan oleh seorang guru bahasa Mandarin sekaligus panitia Hanyu Shuiping Kaoshi (HSK) yang merupakan seorang yang pakar di bahasa Mandarin khususnya HSK di Pekanbaru didapatkan hasil bahwa aplikasi yang dibuat telah sesuai dengan standar Hanyu Shuiping Kaoshi (HSK) sehingga aplikasi yang dibangun dapat dijadikan aplikasi untuk pembelajaran HSK yang sesuai untuk pengguna yang ingin mempelajari HSK.

\section{Pengujian Berpasangan (paired sample)}

Hal yang dilakukan pada pengujian ini adalah pengumpulan data terhadap member/pengguna sebelum menggunakan aplikasi dan sesudah menggunakan aplikasi. Pengujian ini dilakukan oleh 30 orang secara acak. Kemudian dilakukan paired sample 1 test dan statistik deskriptif terkait data yang diolah normal atau tidak. Dimana proses pengujian statistik yang telah dilakukan adalah:

a. Penentuan rumusan hipotesis, baik $\mathrm{H}_{0}$ maupun $\mathrm{H}_{1}$

$H 0: \mu 2 \leq \mu 1 \quad$ (Rata-rata pengguna sesudah menggunakan aplikasi rata-rata nilai sebelum menggunakan aplikasi). 
$H 1: \mu 2>\mu 1 \quad$ (Rata-rata pengguna sesudah menggunakan aplikasi rata-rata nilai sebelum menggunakan aplikasi).

b. Penentuan tingkat signifikan $(\propto)$ yang diinginkan

Pada penelitian ini tingkat signifikan $(\propto)$ yang digunakan adalah $5 \%$ atau 0,05 . Penggunaan tingkat signifikan sebesar 5\% dikarenakan penelitian ini merupakan data hasil pengamatan di masyarakat dimana terkadang untuk mempelajari bahasa Mandarin masih sulit dilakukan oleh masyarakat umum sehingga penelitian yang dibangun masih dapat ditolerir kesalahan kecilnya.

c. Penentuan nilai kritis berdasarkan $\propto$ diatas $95 \%$.

Nilai kritis atau nilai kepercayaan yang digunakan adalah

d. Penentuan statistik uji yang cocok untuk menguji hipotesis nol.

Penelitian ini diuji pada 30 orang pengguna dimana pengguna diberikan soal HSK 4. Maka perbandingan dilakukan pada nilai rata-rata siswa setelah menggunakan aplikasi dengan sebelum menggunakan aplikasi. Dalam kasus ini statistik uji yang cocok untuk menguji hipotesa nol adalah paired sample t-test (uji rata-rata sampel berhubungan).

e. Perhitungan nilai statistik uji berdasarkan data yang diketahui dari populasi atau sampel

Untuk melakukan paired sample t-test, tentukan dahulu apakah data yang akan diolah tersebut merupakan data yang normal berdasarkan analisis statistik deskriptif. Kemudian dilakukanlah analisis seperti tabel di bawah:

Tabel 2. Statistik Deskriptif Sebelum. \begin{tabular}{l}
\hline DESCRIPTIVES \\
\hline /VARIABLES $=$ SEBELUM \\
\hline /STATISTICS $=$ ALL \\
\hline
\end{tabular}

VALID CASES $=30$, CASES WITH MISSING VALUE(S) $=0$

\begin{tabular}{lrr}
\hline & 30 & STD ERROR \\
\hline N & 160,27 & 7,75 \\
\hline STEAN & 42,43 & \\
\hline VARIANCE & 1800,64 & \\
\hline KURTOSIS & $-0,14$ & 0,83 \\
\hline SKEWNESS & 0,72 & 0,43 \\
\hline RANGE & 164,17 & \\
\hline MIN & 94,44 & \\
\hline MAX & 258,61 & \\
\hline SUM & 4808,08 & \\
\hline
\end{tabular}

Tabel 3. Statistik deskriptif sesudah DESCRIPTIVES /VARIABLES $=$ SESUDAH ISTATISTICS $=$ ALL

VALID CASES $=30$, CASES WITH MISSING VALUE(S) $=0$

\begin{tabular}{lrr}
\hline & \multicolumn{1}{c}{ STD ERROR } \\
\hline $\mathbf{N}$ & 30 & \\
\hline MEAN & 200,31 & 6,1 \\
\hline STD DEV & 33,4 & \\
\hline
\end{tabular}

\begin{tabular}{lrr}
\hline VARIANCE & 1115,71 & \\
\hline KURTOSIS & $-0,45$ & 0,83 \\
\hline SKEWNESS & 0,74 & 0,43 \\
\hline RANGE & 118,61 & \\
\hline MIN & 156,67 & \\
\hline MAX & 275,28 & \\
\hline SUM & 6009,19 & \\
\hline
\end{tabular}

Berdasarkan data di atas, kemudian dilakukan perhitungan koefisien varians, rasio skewness, dan rasio kurtosis untuk mengetahui apakah data termasuk normal atau tidak.

a. Koefisien Varians

Untuk menentukan data yang didapat tersebut normal, maka nilai Koefisien Varians harus $<30 \%$. Berikut perhitungan $\mathrm{KV}$ :

$\mathrm{KV}($ sebelum $)=(\mathrm{Sd} /$ mean $) \times 100 \%$

$=(42,43 / 160,27) \times 100 \%$

$=26,47 \%$

$\mathrm{KV}($ sesudah $)=(\mathrm{Sd} / \mathrm{mean}) \times 100 \%$

$=(33,4 / 200,31) \times 100 \%$

$=16,67 \%$

Dari perhitungan di atas, disimpulkan bahwa nilai $\mathrm{KV}$ sebelum dan sesudah berada dibawah $30 \%$ dan data yang didapat termasuk normal.

\section{b. Rasio Skewness}

Dalam uji rasio skewness data disebut normal jika hasil uji rentang -2 sampai 2. Berikut perhitungannya :

Skewness (sebelum) = skewness $/$ Std. error skewness

$$
\begin{aligned}
& =0,72 / 0,43 \\
& =1,67
\end{aligned}
$$

Skewness $($ sesudah $)=$ skewness $/$ Std. error skewness

$$
\begin{aligned}
& =0,74 / 0,43 \\
& =1,72
\end{aligned}
$$

Dari perhitungan di atas, disimpulkan bahwa nilai rasio skewness sebelum dan sesudah berada didalam rentang -2 dan 2 sehingga data yang didapat termasuk normal.

\section{c. Rasio Kurtosis}

Dalam uji rasio kurtosis data disebut normal jika hasil uji rentang -2 sampai 2. Berikut perhitungannya :

Kurtosis (sebelum) = kurtosis / Std. error kurtosis

$$
\begin{aligned}
& =-0,14 / 0,83 \\
& =-0,17
\end{aligned}
$$

$$
\begin{aligned}
\text { Kutrosis } \text { (sesudah) } & =\text { kurtosis } / \text { Std. error kurtosis } \\
& =-0,45 / 0,83 \\
& =-0,54
\end{aligned}
$$

Dari perhitungan di atas, disimpulkan bahwa nilai rasio kurtosis sebelum dan sesudah berada didalam rentang -2 dan 2 sehingga data yang didapat termasuk normal.

Dari ketiga pengujian hasil perhitungan secara desktiptif bahwa data yang diolah tersebut merupakan data normal. Selanjutnya dilakukan uji paired sample t-test. Hasilnya dapat dilihat pada tabel dibawah : 
Tabel 4. Paired Sample Statistic.

\begin{tabular}{rrrrrr}
\hline & & MEAN & N & $\begin{array}{c}\text { STD. } \\
\text { DEV }\end{array}$ & $\begin{array}{c}\text { S.E. } \\
\text { MEAN }\end{array}$ \\
\hline PAIR 1 & SEBELUM & 160,27 & 30 & 42,43 & 7,75 \\
\hline & SESUDAH & 200,31 & 30 & 33,4 & 6,1 \\
\hline
\end{tabular}

Tabel 5. Paired Sample Correlation.

\begin{tabular}{ccccr}
\hline & & N & CORRELATION & SIG. \\
\hline $\begin{array}{c}\text { PAIR } \\
\mathbf{1}\end{array}$ & $\begin{array}{c}\text { SEBELUM } \\
\&\end{array}$ & 30 & 0,94 & 0 \\
SESUDAH & & & 0 \\
\hline
\end{tabular}

Tabel 6. Paired Differences.

\begin{tabular}{|c|c|c|c|c|c|}
\hline \multicolumn{6}{|c|}{ PAIRED DIFFERECES } \\
\hline & \multirow[t]{2}{*}{ MEAN } & \multirow[t]{2}{*}{$\begin{array}{l}\text { STD. } \\
\text { DEV }\end{array}$} & \multirow[t]{2}{*}{ S.E. MEAN } & \multicolumn{2}{|c|}{$\begin{array}{l}\text { 95\% CONFIDENCE } \\
\text { INTERVAL OF THE } \\
\text { DIFFERENCE }\end{array}$} \\
\hline & & & & LOWER & UPPER \\
\hline & $-40,04$ & 15,54 & 2,84 & $-45,84$ & $-34,23$ \\
\hline $\begin{array}{c}\text { A } \\
\text { I } \\
\text { LUM - }\end{array}$ & $\mathbf{T}$ & DF & $\begin{array}{c}\text { SIG.(2 } \\
\text { TAILED) }\end{array}$ & & \\
\hline $\begin{array}{ll}\mathbf{R} & \text { DAH } \\
\mathbf{1}\end{array}$ & $-14,11$ & 29 & 0 & & \\
\hline
\end{tabular}

\section{f. Keputusan.}

Tolak $\mathrm{H}_{0}$ apabila hasil statistik terletak pada daerah penolakan $\mathrm{H}_{0}$, sebaliknya terima $\mathrm{H}_{0}$ apabila hasil statistik terletak di daerah penerimaan $\mathrm{H}_{0}$.

Pengambilan keputusan :

i. Perbandingan $\mid t$ hitung $\mid$ dan $\mid t$ tabel $\mid$

Statistik hitung > statistik tabel, maka $\mathrm{H}_{0}$ ditolak.

Statistik hitung < statistik tabel, maka $\mathrm{H}_{0}$ diterima.

Dalam melakukan perbandingan, maka harus menghitung $\mathrm{t}$ terlebih dahulu :

$$
\begin{aligned}
t & =\frac{d}{S d / \sqrt{n}} \\
& =\frac{-40,04}{15,54 / \sqrt{30}} \\
& =-14,11
\end{aligned}
$$

Untuk t tabel dapat dicari pada tabel $\mathrm{t}$ yang ada dengan melihat tingkat signifikan $(\propto)$ sebesar 5\% atau tingkat kepercayaan 95\%. Df (degree of freedom) atau derajat kebebasan dihitung dengan $n-1=30-1=29$. Dari hasil Analisa pertama bahwa t hitung sebesar 14,11>t tabel sebesar 1,311, maka $\mathrm{H}_{0}$ ditolak.

ii. Perbandingan nilai probabilitas

Nilai probabilitas (Sig 2-tailed) $>0,05$, maka $\mathrm{H}_{0}$ diterima. Nilai probabilitas (Sig 2-tailed) $<0,05$, maka $\mathrm{H}_{0}$ ditolak. Pada tabel paired sample $t$ test, dapat dilihat hasil probabilitas (Sig 2-tailed) adalah 0. Dari hasil berikut dapat diambil kesimpulan bahwa nilai probabilitas (Sig 2tailed) $<0,05$, maka $\mathrm{H}_{0}$ ditolak. Maka dapat disimpulkan bahwa aplikasi berhasil secara signifikan yang dapat dilihat pada perbandingan rata-rata siswa sesudah menggunakan aplikasi lebih besar dari pada sebelum menggunakan aplikasi.

\section{KESIMPULAN}

Pada bab ini dilakukan penarikan kesimpulan terhadap pengujian yang telah dilakukan dan saran untuk pengembangan aplikasi.

\section{A. Kesimpulan}

Sistem ini telah diuji dengan pengujian fungsionalitas dan diperoleh hasil bahwa setiap fungsi ataupun proses pada aplikasi ini telah berjalan dengan baik dan memiliki output yang sesuai dengan inputan yang diberikan oleh pengguna. Berdasarkan hasil kuisioner pengujian usabilitas yang dilakukan, didapat hasil skor SUS sebesar 81,2 untuk aplikasi member dan 81 untuk aplikasi admin yang menunjukkan bahwa aplikasi yang dibangun bersifat acceptable. Kosakata, materi, soal-soal latihan, soal-soal ujian yang terdapat di dalam aplikasi ini sudah sesuai dengan standar Hanyu Shuiping Kaoshi (HSK) sehingga aplikasi ini bisa digunakan untuk pengguna yang ingin mempelajari HSK. Berdasarkan hasil pengujian statistik yang dilakukan didapatlah hasil bahwa $\mathrm{H}_{0}$ ditolak dikarenakan nilai t hitung $(14,11)>$ dari $\mathrm{t}$ tabel $(1,311)$ dan nilai probabilitas $(0)<0,05 \%$, dengan kata lain bahwa rata-rata nilai pengguna sesudah menggunakan aplikasi $(160,27)>$ rata-rata nilai pengguna sebelum menggunakan aplikasi (200,31), sehingga aplikasi ini berhasil secara signifikan. Rancang bangun Hanyu Shuiping Kaoshi (HSK) mobile learning berbasis android dapat membantu pengguna dalam melakukan simulasi ujian HSK hingga level 4.

B. Saran

Saran untuk pengembangan aplikasi ini adalah :

1. Perlu adanya pembahasan untuk setiap jawaban yang salah pada menu latihan.

2. Perlu adanya penilaian yang lebih kompleks sehingga pengguna dapat mengetahui nilai yang perlu ditingkatkan.

\section{REFERENSI}

[1] Hanban. (2014). 汉语考试_HSK. Diakses dari: http://www.hanban.edu.cn/tests/node_7486.htm. pada tanggal 24 Januari 2019.

[2] Quinn, C.N. (2010). M-Learning: An Introduction to Mobile Learning. 